\title{
Sturen op het delen van data: tussen lokale oplossingen en een nationaal platform*
}

\author{
Bram Klievink
}

\begin{abstract}
Informatieplatformen kunnen het delen van data vergemakkelijken en maken nieuwe toepassingen mogelijk. Het is essentieel om een breed scala aan zowel publieke als private partijen op een platform aan te sluiten, wil echte datagebaseerde transformatie van de grond komen. Organisaties zijn echter terughoudend in het delen van data als zij niet precies weten waarvoor dit gebruikt kan worden, of als zij daar niet direct belang bij hebben. Tot een goede oplossing te komen vraagt veel van het innovatieproces zelf en de wijze van sturing daarop. Dit artikel gebruikt een drietal innovatieperspectieven voor de analyse van een logistiek informatieplatform. Daaruit blijkt dat er verschillende stadia in de ontwikkeling van een informatieplatform te onderscheiden zijn met ieder een eigen dynamiek. Voor lokaal bestuur is de betrokkenheid van en aansluiting op lokale partijen van belang, terwijl de innovatie als geheel baat heeft bij de koppeling met een overkoepelende agenda die het lokale niveau ontstijgt.
\end{abstract}

\section{Introductie}

Er is steeds meer aandacht voor de rol die data kunnen spelen in het creëren van waarde voor de samenleving. Overheden en semioverheidsorganisaties stellen bijvoorbeeld datasets ter beschikking aan anderen, in de hoop dat een breder gebruik en hergebruik van gegevens kunnen leiden tot datagedreven innovaties en het vergroten van transparantie, of nieuwe diensten en toepassingen mogelijk maken die tot economische groei leiden (Estermann e.a., 2018; Meijer, 2018; Zuiderwijk \& Janssen, 2014). De belofte gaat verder dan enkel het beschikbaar stellen en gebruiken van data; zo werken diverse landen individueel en op Europees niveau aan strategieën voor een data-economie (Klievink e.a., 2017).

Datagedreven innovaties kunnen een krachtig instrument zijn voor het openbaar bestuur, dat in toenemende mate gericht is op de waarde van inclusieve benaderingen en samenwerking in horizontale 'genetwerkte' omgevingen (Ansell \& Gash, 2007; Bryson e.a., 2006; De Bruijn \& Ten Heuvelhof, 2018; McGuire e.a., 2010; Stoker, 2006). De overheid kan voordeel hebben bij samenwerking met partijen buiten de publieke sector. Die samenwerking hoeft niet per se vanuit

* Het onderzoek waarop dit artikel is gebaseerd, maakte deel uit van het onderzoeksproject 'Governing public-private information infrastructures', gefinancierd door de Nederlandse Organisatie voor Wetenschappelijk Onderzoek (NWO) als Veni-beurs 451-13-020. Dit artikel is mede gebaseerd op een bewerking van een tweetal gepubliceerde Engelstalige wetenschappelijke artikelen (Klievink e.a., 2016; 2018), gecombineerd met nog niet gepubliceerd materiaal uit een working paper van de auteur tezamen met Albert Meijer. 
bepaald beleid of een bepaalde dienst te worden ingestoken, maar kan ook starten met het uitwisselen en bij elkaar brengen van data (Klievink e.a., 2018). Op basis van dit soort 'data collaboratives' kan dan worden gekeken op welke wijze beleidsproblemen op te lossen zijn en of er op andere wijze publieke waarde kan worden gecreëerd (Susha e.a., 2017; Verhulst \& Sangokoya, 2015). De combinatie van datagedreven innovaties en een openbaar bestuur dat is gericht op samenwerking biedt kansen voor innovaties die zowel publieke als individuele en commerciële voordelen kunnen opleveren. Door aan te haken bij - en mee te sturen op - digitale innovaties kunnen overheden proberen meer gebruik te maken van de innovaties van en door anderen. In plaats van innovaties te initiëren en organiseren, kan de overheid zich andere rollen aanmeten, bijvoorbeeld door op slimme wijze prikkels te creëren zodat anderen hun innovaties zo inrichten dat er ook een publiek belang mee wordt gediend (Irani e.a., 2007; Janssen \& Estevez, 2013; Weerakkody \& Dhillon, 2008).

Voorbeelden als Standard Business Reporting (Bharosa e.a., 2013) en Extended Single Windows (Klievink e.a., 2016) laten zien dat innovaties die de bestaande informatie-uitwisseling tussen bedrijven als basis nemen, heel goed kunnen worden ingezet om informatievergaring van de overheid efficiënter en effectiever te maken. Niet alleen kunnen overheidsorganisaties meeliften ('piggybacken') op de verbeterde interoperabiliteit en uitwisseling door bedrijven, ook creëert de combinatie van publieke en private data nieuwe mogelijkheden (Klievink e.a., 2016). Een op samenwerking gerichte benadering sluit aan bij het idee dat in datagedreven innovatie echte toegevoegde waarde kan worden gerealiseerd door data uit verschillende bronnen op slimme wijze te combineren en integreren (Klievink e.a., 2016; Susha e.a., 2017). Een voorbeeld uit het domein van de casus in dit artikel: als men in de haven detailinformatie over de inhoud van een goederencontainer (afkomstig van de eigenaar) combineert met informatie over scheepsbewegingen en aankomst (van de rederij), en de planning in de haven (onder andere van de terminal) met gegevens van de overheid over inspecties en vrijgave, kan het vervolgtransport beter worden georganiseerd. Dat leidt tot meer efficiëntie in de haven, beter toezicht en vermindering van uitstoot door slecht gepland vrachtverkeer.

Hoewel een gesimplificeerd voorbeeld, vereist dit wel dat de betrokken partijen hun informatie ook ter beschikking willen stellen aan anderen, ten behoeve van toepassingen waar ze niet noodzakelijk zelf veel voordeel bij hebben. Dit impliceert een verlies aan controle. Sterker: als het uitgangspunt is om nu data te delen teneinde straks nieuwe toepassingen te kunnen creëren, weten partijen niet bij voorbaat voor welke toepassing ze hun data ter beschikking stellen. Dat brengt onzekerheid en potentiële kwetsbaarheden met zich mee (Eaton e.a., 2015). Als gevolg hiervan kunnen partijen ervoor kiezen niet aan te sluiten bij een datadelingsplatform of om slechts beperkte, verouderde of sterk bewerkte informatie te delen. Dat kan de toegevoegde waarde van zo'n innovatie aanzienlijk beperken.

De grote diversiteit aan doelen en vraagstukken en de veelheid aan partijen die daarbij betrokken is of kan worden, leiden tot aanzienlijke complexiteit (Stoker, 
2011). Ook aan overheidszijde spelen meerdere doelen en belangen. Handel en logistiek kennen een sterke internationale component, Europese regelgeving, diverse nationale belangen zoals vestigingsklimaat en toezicht, en lokale belangen die bijvoorbeeld met bereikbaarheid, leefbaarheid en lokale bedrijvigheid te maken hebben. De belangen van het lokaal bestuur en de nationale overheid liggen hierbij niet noodzakelijk in elkaars verlengde. Om lokale bedrijvigheid en andere belangen een plek te geven is contextspecifieke innovatie wenselijk, terwijl het internationale karakter en het nationaal belang juist vragen om harmonisering van initiatieven. Een lokaal inclusieve innovatiestrategie lijkt moeilijk te rijmen met een meer sturende aanpak vanuit de nationale overheid en het internationale bedrijfsleven.

De centrale vraag in dit artikel is hoe, tegen de achtergrond van deze complexiteit, gestuurd kan worden op het proces van een datagedreven innovatie. Hiertoe wordt in de volgende paragraaf een drietal theoretische perspectieven beschreven. Aan de hand daarvan wordt een casus onderzocht waarin een nationale agenda sturing probeert te geven aan innovaties richting een logistiek informatieplatform dat ook lokaal gedragen moeten worden.

\section{Achtergrond}

Er wordt onderzoek gedaan naar het gebruik van digitale platformen om diverse partijen in samen te brengen en de onderlinge informatie-uitwisseling te verbeteren (Bharosa e.a., 2013; Janssen \& Estevez, 2013; Klievink e.a., 2016). Hoewel er ontzettend veel werk te verzetten is op technisch vlak, is ook het sturingsvraagstuk over zowel het platform als het proces daarnaartoe uitdagend.

Zo moet een balans worden gevonden tussen enerzijds voldoende sturing en controle op het platform en anderzijds het respecteren van vrijwilligheid en autonomie. Dat eerste is nodig zodat het ook daadwerkelijk van de grond komt, partijen op uniforme wijze gegevens aanleveren, en deze gegevens gebruikt kunnen worden om daadwerkelijk toepassingen te ontwikkelen. Deze waarde wordt groter naarmate een groter deel van een bepaalde community meedoet en naarmate zij betere informatie leveren en meer gebruik ervan toestaan. Bij te dwingende of te eenzijdige sturing kan het weinig aantrekkelijk zijn om belangrijke data over te dragen aan een platform waarover de partij dan zelf weinig controle meer heeft. Deze spanning tussen de noodzaak van zelfbeschikking over eigen data ('control') en de noodzaak die los te laten om het platform echt meerwaarde te doen creëren ('generativity'), is vrij uitgebreid beschreven in de literatuur op dit vlak (Eaton, 2012; Markus \& Bui, 2012).

Wat hier van belang is, is het opzetten van een enigszins formele sturingsstructuur en besluitvormingsprocessen ten aanzien van het platform (Von Tunzelmann, 2003). Dit omvat zaken als regels, afspraken, rolverdelingen, beslissingsbevoegdheden en institutionele arrangementen om al die verschillende partijen onderling te laten afstemmen en een plek te geven in het platform (Cusumano, 
2005; Lynn e.a., 2000). Uit onderzoek naar private platformen blijkt echter dat te veel hiërarchische sturing contraproductief kan zijn voor een succesvol platform (Gawer, 2014). Het is essentieel om de sturing van het platform zo in te richten dat partijen erop vertrouwen en hun data openstellen ten behoeve van de samenwerking (Thomson \& Perry, 2006). Aangezien het delen van data kwetsbaar maakt, kan de deelname van een overheidsorganisatie faciliterend werken, omdat neutraliteit dan beter is gewaarborgd. Tegelijkertijd brengt de betrokkenheid van een overheidsorganisatie zelf ook uitdagingen met zich mee die een effect hebben op de bereidheid van private partijen om mee te doen (Klievink e.a., 2018). Zo spelen wederkerigheid en belangenoverwegingen een belangrijkere rol dan in meer traditionele bedrijf-overheidinteracties, die gebaseerd zijn op noodzaak (bijv. wettelijke eis) of legitimiteit (Barringer \& Harrison, 2000; Oliver, 1990). Bij sterke overheidssturing is er tevens een risico dat aanzienlijke delen van het platform uiteindelijk de verantwoordelijkheid van de overheid worden, wat het eerder een traditioneel overheidsportaal maakt dan een echte samenwerking.

Innovatieprocessen raken dus aan de strategieën en operaties van een diverse set aan partijen, variërend van de technologieaanbieders tot dienstverleners, eindklanten en alle andere belanghebbenden. De Bruijn en collega's (2004) benadrukken dat het gedrag van al die actoren gebaseerd is op andere waarden, belangen of posities. Het is daarom van belang om te zoeken naar de waarde(n) die individuele partijen delen met de bredere context (Porter \& Kamer, 2011), in dit geval omvat die dus ook concurrenten en overheden. Bij publiek-private samenwerking komt daarbij dat overheden en bedrijven hele andere redenen hebben om aan te sluiten bij een platform. Dit maakt besluitvorming over een goede inrichting van de innovatie complex (Van Gestel e.a., 2008). In de literatuur zijn diverse strategieën te vinden ten aanzien van het sturingsvraagstuk voor dit soort complexe innovaties. In deze paragraaf worden er drie besproken, die als analytisch kader dienen.

Waar het opzetten van een datadeelplatform als technische innovatie kan worden gezien, is de onderliggende verandering groter. Als partijen, die in hun primaire product of dienst concurrenten zijn, onderling grootschalige datadeling gaan opzetten - en als overheden hun modus van informatiecollectie wijzigen van het voorschrijven naar het ergens bij aansluiten - is dit een vrij vergaande verandering in de interactie tussen die partijen. Hier past mogelijk een transitieperspectief bij. Transities worden gekenmerkt door een focus op de lange termijn, het domein- en actoroverstijgend karakter en systemische innovatie (Rotmans e.a., 2001). Het managen van transities is een veld op zich geworden (Loorbach, 2010). Dat suggereert dat een transitie dan ook gemanaged kan worden, hoe moeilijk het ook is om verandering te bewerkstelligen in zo'n context. Belangrijke elementen in transitiemanagement zijn het hebben van een visie, doel, tussendoelen en het leren door te experimenteren en evalueren (Rotmans e.a., 2001). Door de complexiteit, de belangentegenstellingen en het soms ronduit contra- 
intuïtieve karakter lijkt het echter lastig om een echte transitie te managen als een doelgericht proces.

Een andere kijk op hoe innovaties aanslaan, is die vanuit het 'sociale innovatie'perspectief. In dat perspectief moeten echte veranderingen van economische en sociale praktijken geworteld zijn in kleinschalige, lokale, sociale innovaties, gebaseerd op consensus over een bepaalde oplossing (Heiskala, 2007; Rüede \& Lurtz, 2012). Alleen dan valt er om te gaan met de grote diversiteit aan waarden, doelen en belangen van de betrokken partijen, die anders een te grote belemmering zouden vormen om echt iets van de grond te krijgen. Initiatieven gericht op het delen van data hebben wel enkele kenmerken van sociale innovaties (Klievink \& Janssen, 2014). Sociale innovaties zijn in zekere zin transities in het klein: lokaal, met soms tijdelijke oplossingen en gedreven door consensus onder actoren die direct betrokken zijn. Vanuit die innovaties ontstaan nieuwe werkwijzen, organisatievormen of nieuwe regels die oudere gebruiken langzamerhand vervangen, geïnstitutionaliseerd raken en uiteindelijk steeds breder gebruikt worden (Zapf, 1991, zoals aangehaald in Rüede \& Lurtz, 2012). Dit perspectief van lokaal geïnitieerde en gedreven innovaties sluit aan bij het idee van 'local governance', waarin de netwerkfunctie van het lokaal bestuur centraal staat (Stoker, 2011).

De twee perspectieven staan niet helemaal los van elkaar: een gecoördineerde bundel van sociale innovaties kan een transitie bewerkstelligen - en een goed gecoördineerde transitie kan sturing en richting geven aan kleinere, sociale innovaties en gebruik maken van het commitment dat partijen daaraan geven. Lokale overheden zouden sociale innovaties kunnen bevorderen om zowel lokale als meer algemene doelen te bereiken, al dan niet afgestemd op een nationale transitieagenda. Beide perspectieven kunnen bijdragen aan het begrip waarom het zo lastig is om in samenwerking een platform voor het delen van data te bouwen.

Toch zit er ook enige spanning tussen het idee van een gestuurde transitie op basis van een overkoepelend doel en het idee van meer emergente innovaties die voortkomen uit lokale samenwerking. Beide hebben hun voordelen. Het ene geeft handvatten voor het coördineren van innovaties op algemeen niveau. Het andere kan adoptie bevorderen in concrete situaties door middel van aanpassing aan de variantie in de waarden, doelen en belangen van een beperkte en specifieke set actoren. Maar kleinschalige, consensusgeoriënteerde innovaties dragen niet als vanzelf bij aan een grotere (al dan niet gedeelde) agenda en het spreekt net zomin voor zich dat er synergie zit in verschillende sociale innovaties.

Een derde perspectief combineert in zekere zin deze innovatie-ideeën. Strategisch 'nichemanagement' richt zich op het creëren van 'niches' waarin geïnnoveerd kan worden op een wijze die bijdraagt aan een grotere transitie. Niches zijn beschermde omgevingen waarin geëxperimenteerd kan worden met de 'co-evolutie' van technologie, de gebruikspraktijk en regelgeving (Schot \& Geels, 2008: 537). Omdat bestaande praktijken en instituties (te) veel druk zouden uitoefenen op de ontwikkelingen in dergelijke niches, is het van belang om die niches (tijdelijk) te beschermen (Boon e.a., 2014). Nichemanagement gaat dan om het gericht 
sturen op nichevorming, waarbinnen technische innovaties in context kunnen worden ontwikkeld (Loorbach \& Van Raak, 2006). De literatuur op dit vlak biedt diverse strategieën voor de bescherming van deze niches, met name op het gebied van omgang met belanghebbenden, consensus en compromis, het betrekken van actoren en het faciliteren van het leren van het proces (Boon e.a., 2014).

Ten opzichte van transitiemanagement en sociale innovaties biedt strategisch nichemanagement het perspectief van niche-innovaties die kunnen leiden tot meer systemische verandering. Ten opzichte van transitiemanagement doet het meer recht aan de actorcomplexiteit, doordat innovaties eerst enige volwassenheid bereiken alvorens ze echt in wijdverbreid gebruik worden genomen. In die zin is het een meer van onderop gedreven proces dat is gericht op het verwerven van een zekere achterban die achter de innovatie staat (Schot \& Geels, 2008). Ten opzichte van sociale innovaties ligt er bij strategisch nichemanagement meer nadruk op het leren en netwerken ten behoeve van het doen ontstaan van regels die uiteindelijk ook breder worden gedeeld. Het geeft daarin een pad van hoe diverse kleinere innovaties uiteindelijk samen kunnen komen in een grotere wijziging.

Samenvattend: transitiemanagement kan helpen om te begrijpen hoe de algemene ontwikkeling op het gebied van data delen vorm krijgt. Het perspectief van sociale innovaties benadrukt hoe concrete verandering in een specifieke context speelt en het strategisch nichemanagement geeft aan dat deze twee met elkaar verbonden moeten worden, wil een innovatie grootschalig en voor de lange termijn worden opgepikt. Binnen eenzelfde innovatieproces bestaan diverse fases waarin kenmerken van deze drie perspectieven terug kunnen komen. Hun relatieve belang zal echter variëren naargelang de context en fase van het innovatieproces.

\section{Casus: data delen in de haven}

De vraagstelling wordt onderzocht aan de hand van een casus. Deze casus speelt zich af rondom het opzetten van een logistiek informatieplatform, dat als doel heeft om het delen en (her)gebruiken van data in de logistieke sector te faciliteren en versterken. Nederland speelt een belangrijke rol in de mondiale logistiek en deze leunt sterk op informatie. Er spelen allerlei informatiestromen richting de overheid, zoals import- en exportaangiftes en de diverse meldingen en aangiftes met betrekking tot het binnenbrengen van goederen. Ook vindt er veel gegevensuitwisseling plaats tussen partijen onderling en binnen logistieke community's.

Een belangrijke community is die rondom de haven, waar rederijen, terminals, cargadoors, stuwadoors, vervolgtransport, opslag, de havenmeester, Douane, de Nederlandse Voedsel- en Warenautoriteit (NVWA) en vele andere partijen betrokken raken bij de vele goederenstromen die door de haven lopen. Veelal hebben zij gegevens die in combinatie met data van anderen nodig zijn om logistieke en administratieve processen in de haven goed te laten verlopen. Om die reden 
wordt het delen van data gezien als belangrijke factor die de logistiek en de leidende rol van Nederland daarin mogelijk maakt. Als onderdeel van de roadmap voor de Topsector Logistiek is daarom stevig ingezet op de transformatie van de informatiefunctie in de sector, onder de noemer Neutraal Logistiek Informatie Platform (NLIP). Via dit platform moet logistieke informatie worden gedeeld, waarbij zowel publieke als private en communityfunctionaliteiten ondersteund en mogelijk gemaakt moeten worden.

Het NLIP-programma legde sterk de nadruk op het (her)gebruik van informatie, onder andere door apps en API's te ontwikkelen waarmee de data niet alleen bestaande functionaliteit, maar ook nieuwe toepassingen kunnen ondersteunen. Deze nieuwe toepassingen maken bijvoorbeeld efficiëntere en duurzamere logistieke ketens mogelijk. De kern van de data, functionaliteit en meerwaarde zou privaat moeten zijn. De overheid is verantwoordelijk voor (proces)optimalisaties aan overheidskant en committeerde zich eraan dat het NLIP het belangrijkste portaal zou worden, waarbij er in principe geen andere portalen ontwikkeld zouden worden. Tevens legde ze de intentie vast om met de markt te kijken naar oplossingen die voor de combinatie van markt en overheid het beste zijn. Ten slotte committeerde de overheid zich eraan de ontwikkeling en het gebruik van het NLIP te stimuleren. Het NLIP als programma en organisatie werd ook gefinancierd door de overheid.

Het programma startte in 2010 met als basis de bestaande communitysystemen, niet alleen die in de zeehavens, maar ook die van de luchthaven en een aantal sectorspecifieke communitysystemen. Een platform van platformen dus. Het proces richtte zich in eerste instantie vooral op het bewerkstelligen van overeenstemming over de (technische) standaarden, de toe te laten functionaliteit en de governance van het platform. Inmiddels is het beeld van een grootschalig nationaal platform deels losgelaten omdat de werkelijke opzet en uitrol ontzettend lastig bleken. Nu richt men zich op het coördineren van een aantal kleinere initiatieven, in een poging om daarmee de gedachte van het platform te realiseren. Dit laat precies de eerder geschetste spanning zien tussen het grote idee van een transitie en de incrementele stappen daartoe. De geanalyseerde periode beslaat de eerste zes jaar van het programma, waarin verschillende fases te onderscheiden zijn. Ieder van die fases heeft eigen kenmerken, maar in combinatie laten ze zien hoe in het programma is omgegaan met de uitdaging om de transitie te managen, terwijl er ook recht moest worden gedaan aan de belangen van die veelheid aan partijen die deze innovatie moeten dragen, wil het echt een transitie worden. In deze casus valt te bestuderen hoe lokale en specifieke innovaties interacteren met een grotere transitieagenda. De analyse is gebaseerd op dertien interviews en analyse van openbare documenten die over het NLIP-programma zijn gepubliceerd. Omwille van eventuele gevoeligheden zijn namen van mensen of organisaties achterwege gelaten in dit artikel. De interviews zijn gehouden met vertegenwoordigers van ministeries, Douane, twee platformaanbieders, bedrijven in de logistieke sector en een tweetal koepelorganisaties. De interviews richtten zich op de betrokkenheid van de partijen, de gewenste en mogelijke functionali- 
teit, de belangen van de diverse partijen, de governance-uitdagingen, en de wijze waarop daarmee is omgegaan. De interviews duurden drie kwartier tot negentig minuten en zijn getranscribeerd. Op basis van de interviews en documenten is het narratief geconstrueerd dat in paragraaf 4 is beschreven. Deze beschrijving is opgedeeld in diverse fases, die het resultaat zijn van een analyse van het verkregen materiaal. Ter validatie is deze lijn besproken met een manager die direct bij het proces betrokken was.

\section{Chronoloog: een platform in vier stappen}

\subsection{Stap 1: visie en opstarten}

De opstartfase was vooral gericht op het aangehaakt krijgen van de belangrijkste stakeholders. Dit was van belang omdat het uitgangspunt van het programma was dat belangrijke innovaties alleen mogelijk waren als die partijen data ter beschikking zouden stellen aan derden. De programmamanager die bij deze fase betrokken was, investeerde vooral in commitment van stakeholders voor de visie dat bestaande publieke, private en communitysystemen en platformen met elkaar verbonden zouden worden. Dat zou een groot aantal partijen - en hun data - aan elkaar koppelen. Door slimme combinaties van data en functionaliteiten te maken konden innovatieve 'apps' worden ontwikkeld waar die stakeholders en de sector in het algemeen baat bij zouden hebben.

Deze eerste fase ging vooral over het opzetten van de architectuur van het platform, met name met betrekking tot de datamodellen en interfaces. Ook is er direct veel geïnvesteerd in het opzetten van een governancestructuur. Het ging hier vooral om het ontwikkelen van een goede basis voor de transitie naar een meer datagedreven sector, zowel technisch als wat betreft stakeholdermanagement. Er werd een inclusieve aanpak gehanteerd: alle belangrijke groepen belanghebbenden werden in de governancestructuur betrokken, direct of via hun koepels. De overheid opereerde hierin als één stakeholder, hoewel er in feite drie ministeries en twee uitvoeringsorganisaties bij betrokken waren, ieder met eigen doelen. Ondanks het grote belang van de overheid bij betere datadeling stelde zij zich enigszins terughoudend op en liet de ruimte aan de bedrijven en bestaande platformen om tot een uitwerking te komen. Dit was ten minste ten dele ingegeven door de angst dat een te grote rol in dit proces ertoe kon leiden dat de overheid de verantwoordelijkheid en kosten voor (het ontwikkelen van) het hele platform toegespeeld zou krijgen door de bedrijven.

Deze aanpak werkte de eerste anderhalf jaar, in de zin dat er een gedeeld beeld ontstond bij wat het platform zou moeten zijn en kunnen, wat leidde tot een convenant waarin het transitiedoel werd vastgelegd. Het ging in deze fase echter voornamelijk over de voorwaarden, het ontwerp van het platform en de bijbehorende governance, zonder dat er echte stappen werden gezet in het werkelijk datagedreven transformeren van de sector. 


\subsection{Stap 2: subdoelen en -projecten}

$\mathrm{Na}$ ongeveer een jaar of twee werd meer ingezet op het sturen van het innovatieproces zelf. Dit viel samen met de komst van een nieuwe programmamanager - gefinancierd door de nationale overheid - die meer een projectmanagementaanpak hanteerde om het algemene idee te vertalen naar werkelijke activiteiten, met instrumenten als deadlines en 'verkeerslichten'. Echter, een informatieplatform met zoveel betrokkenen laat zich moeilijk managen als project. In deze fase werd dan ook duidelijk dat achter de gedeelde visie aanzienlijke verschillen tussen de partijen schuilgingen. Een aantal van de partijen had wél een formele rol in de governance van het platform, maar eigenlijk weinig belang bij het van de grond krijgen van het platform. Sterker nog, het beschikbaar stellen van data via het platform paste niet in hun businessmodel en zou daar in enkele gevallen zelfs tegen ingaan. Iedere keer als er mogelijke toepassingen op tafel kwamen, ging het al snel weer over de belangen en posities van partijen - en de kwetsbaarheden die het breder delen van data daarvoor met zich mee zou brengen. Een andere uitdaging was dat het convenant deels was getekend door koepels die moeite hadden hun bedrijfstak mee te krijgen in daadwerkelijke activiteiten. Voor partijen in die achterban was het programma als geheel erg ver weg, terwijl ze wel werden geacht er iets mee te doen. Dit speelde vooral bij de vele partijen die primair lokaal opereren. De digitaliseringsgraad en het relatieve belang bij een grootschalig platform zijn bij dergelijke partijen vaak lager. Voor de lokale overheid zijn dat soort partijen echter van belang voor lokale bedrijvigheid en economie. Echter, de lokale overheid had geen stoel aan tafel en kon deze belangen alleen bij anderen inbrengen, zoals het Havenbedrijf en het ministerie.

Het gebrek aan tastbare resultaten en een steeds terugkomende, haast existentiële discussie over wat de aard van het platform zou moeten zijn, zorgden voor toenemende ontevredenheid bij de belanghebbenden, wat tot een neergaande spiraal leidde.

\subsection{Stap 3: resultaten}

De diversiteit in partijen in de logistieke sector is groot, wat het lastig maakt om tot datagebaseerde toepassingen en innovaties te komen waar iedereen mee uit de voeten kan. Goed aansluiten bij de belangen, waarden, posities, branche en omgang van de verschillende partijen is essentieel om iets voor elkaar te krijgen, maar ontzettend moeilijk om tegelijkertijd te doen voor een groot scala aan spelers.

Een aantal subprojecten uit de vorige fase liep beduidend beter dan het programma als geheel. Deze subprojecten waren gericht op specifieke logistieke en informatiestromen, met duidelijke afbakening en een beperkte groep van betrokken partijen. Ook waren de doelen veel helderder en tastbaarder en hadden de ondernomen stappen vrij direct een impact. Dit alles maakt dat er ook snel geleerd kon worden; er werden immers echt stappen gezet in plaats van een doorlopend gesprek over gedeelde ambities en algemene concepten. In een van de subprojecten begonnen de partijen klein, met een specifieke goederenstroom en met 
een beperkte set aan te delen informatie, die alleen voor enkele partijen beschikbaar werd gesteld. Belangrijk onderdeel van de propositie was steeds ook wat de overheid hiermee kon, met name in de vorm van het ondersteunen van toezicht door Douane of NVWA. Deze partijen konden met de extra functionaliteit of data deze specifieke goederenstromen beter faciliteren, wat een belangrijke prikkel vormt voor de private partijen om mee te doen. Echter, ook in dit traject liepen de partijen tegen tal van uitdagingen aan, van interoperabiliteit en (commercieel) gevoelige data tot afspraken over welk soort functionaliteit met welk soort data mogelijk gemaakt mocht worden. Door dit op te lossen voor concrete casus ontstond een stabiele basis, die werd uitgebreid naar andere modaliteiten en goederenstromen. De basis was steeds een vrij beperkte groep betrokken partijen die gaandeweg een modus vonden in het omgaan met hun verschillende belangen.

Belangrijk hier is dat er ook concrete businesscases waren voor het delen van deze data en de toepassingen die erop werden gebaseerd. De aanwezigheid van het overkoepelende programma zorgde voor een stabiele context en bescherming tegen onder andere juridische obstakels. Wat dat betreft valt dit subproject te zien als een niche die werd beschermd door de structuren die waren opgezet voor de grotere transitie, waar deze onderdeel van was. De lessen die in deze pilots werden geleerd, lieten zich echter lastig vertalen naar het overkoepelende programma. Zo verging het ook enkele andere subprojecten; hoewel die op zich vrij succesvol waren en er daadwerkelijk data werden gedeeld, bleek dit niet schaalbaar om ook soortgelijke uitdagingen op te lossen die op het programmaniveau speelden. Er was nu wel een aantal concrete businesscases, maar die brachten het nationale informatieplatform niet noodzakelijk veel verder. Omdat deze (relatief) succesvolle toepassingen als aparte projecten werden georganiseerd, in plaats van als niche-innovatieproces, leek de fragmentatie alleen maar te groeien en het ideaal van een nationaal platform steeds verder weg.

\subsection{Stap 4: terug naar de tekentafel}

Inmiddels was er een nieuwe (de derde) programmamanager aangesteld, specifiek vanwege zijn plannen om nogmaals commitment te winnen voor het informatieplatform. Opnieuw werd er gestuurd op een gedeeld, breedgedragen idee, dat als ijkpunt kon dienen voor steeds kleine aanpassingen en vernieuwingen bij de belangrijkste spelers. Die focus op wat partijen vanuit hun bestaande praktijk konden doen om steeds dichter bij het idee achter het platform te komen, was hierin belangrijker dan het sturen op specifieke subprojecten.

Als eerste stap werd de focus op details van het platform als technisch object losgelaten. In plaats daarvan kwam de visie centraal te staan, en daarmee de partijen die die visie onderschreven zonder al te veel te kijken naar de praktische implicaties daarvan voor hun organisatie. Dit hing sterk af van de betrokken individuen; een aantal kernpartijen werd in het programma vertegenwoordigd door mensen die zich richtten op de langetermijnvisie, ook als die niet strookte met het huidige businessmodel van hun organisatie. Deze groep is langzamerhand een nieuw governance-instrument geworden binnen het programma. De groep is opdrach- 
ten gaan uitzetten om concrete dingen (applicaties, API's, datakoppelingen, dashboards, etc.) te ontwikkelen, vanuit die gedeelde visie. Deze opdrachten werden vervat in overeenkomsten en contracten, met het programma als opdrachtgever. Hierdoor is er veel meer sturing mogelijk, gericht op concrete doelstellingen. Er is dan niet langer een projectleider die namens het programma als geheel werkt. De opdrachten kennen ieder hun eigen projectmanagement en aansturing, en daarin is vrijheid zolang ze voldoen aan de opdracht - en daarmee dus bijdragen aan de langetermijnvisie.

De 'oudere' governancestructuren uit de eerdere stappen van het proces bestaan echter ook nog en daarin zijn veel meer partijen vertegenwoordigd. Daaronder dus een aantal partijen die geen prikkel hebben voor een deel van de (of zelfs alle) innovaties die met het platform voor datadeling beoogd werden. Zij komen moeilijk los van hun bestaande rol in het informatie-/logistieke proces en van hun bestaande businessmodellen. Veel van het innovatiemanagement bestond (aan het eind van de analyseperiode in 2016) uit het beschermen van de opdrachten en deelprojecten die zijn uitgezet op basis van hun bijdrage aan de overkoepelende transformatie.

\section{Analyse}

Door dit proces analytisch op te knippen in fases vallen de ontwikkelingen en de interactie tussen de algemene transitie en specifieke niche-innovaties beter te begrijpen. De drie theoretische perspectieven - sociale innovatie, strategisch nichemanagement en transitiemanagement - spelen allemaal een rol in het verklaren van de loop van dit innovatieproces. In termen van de drie innovatieperspectieven is het proces als volgt te zien.

In eerste instantie definiëren een aantal overheidspartijen op met name nationaal en uitvoerend niveau en een aantal machtige private spelers een brede doelstelling en proberen de transitie naar een nationaal informatieplatform te sturen. De nadruk ligt op het doel en op een poging dit als transitie te managen. Echter, omdat die transitie te breed en groots is om alle variëteit in waarden, doelen en belangen van alle betrokken partijen te accommoderen, komt de werkelijke transitie lastig van de grond.

Vervolgens verschuift de focus de andere kant op; er wordt veel ruimte gegeven aan kleine groepen belanghebbenden, die veel kleinschaliger veranderingen bewerkstelligen die losjes verband houden met de algemene doelstelling. Het gevolg hiervan is een aantal deeloplossingen die goed passen bij de specifieke situatie waarin ze ontworpen zijn en daar ook werkelijke verandering bewerkstelligen. Een dergelijke bottom-up benadering past bij het sociale-innovatiedenken. Maar samen tellen die deeloplossingen niet op tot echte stappen op de overkoepelende agenda. Het leerproces lijkt beperkt te blijven tot de lokale innovatie. Daarbij is het voor de bedrijven van groot belang dat ook toezichthouders bediend worden door het dataplatform, omdat die hun voordelen (sneller en betere data) 
'belonen' door de betrokken goederenstromen beter te faciliteren. Dat schaalt echter niet makkelijk en zolang het bij een klein deel van de totale goederenstromen blijft, blijft het maatwerk zonder systemische verandering. Daardoor ontstaat een noodzaak voor een derde aanpak, waarin de waarde van die kleine innovaties (d.w.z. acceptatie en implementatie door partijen) gecombineerd kan worden met die van de transitie (d.w.z.. de sector als geheel verder brengen).

Om dit laatste mogelijk te maken bleek opnieuw een verandering nodig in de wijze van aansturing van het programma. Die verandering laat zich duiden aan de hand van het strategisch nichemanagementperspectief. De focus ligt hier op het definiëren en beschermen van niche-innovaties, waarvan vooraf duidelijk is hoe ze passen binnen het overkoepelende programma. Het is van belang om deze kleine innovaties te beschermen, aangezien er voldoende partijen aangehaakt zijn bij het overkoepelende programma die een prikkel hebben de niche-innovatie te verstoren, ook al zijn ze formeel gecommitteerd aan het achterliggende doel. Daarmee is er in het programma meer lijn gebracht in de sociale innovaties, zodat die gezamenlijk bijdragen aan het transitieperspectief. In feite combineert deze aanpak de voordelen van sociale innovaties met het transitiedenken.

Het innovatieproces is nauw verwant aan de inrichting van de sturing van het platform. In dit geval is er een inclusieve governancestrategie gevoerd, gericht op het betrekken van veel partijen die in de sector actief zijn. Mede doordat het informatieplatform voortbouwt op bestaande systemen, zit er op diverse plekken een behoorlijke ongelijkheid in dat actorveld. Aan de platformkant zijn er enkele sterke spelers die al veel van de data en techniek in huis hebben. Aan de logistieke kant zijn er een paar mondiaal opererende partijen en een veelheid aan kleinere, lokaal opererende partijen. Aan de overheidskant ten slotte, is er sprake van diverse organisaties die de komst van het platform wel willen faciliteren, maar ervoor waken de bal zelf niet toegespeeld te krijgen. Met gedistribueerd eigenaarschap en gedeelde beslissingsbevoegdheden bleek het moeilijk om deze actorcomplexiteit het hoofd te bieden. De casus is nog steeds in ontwikkeling, maar vooralsnog lijkt de opschaling vanuit de niches een grote uitdaging te blijven. Dat is ten minste deels te verklaren doordat de gevestigde systemen en werkwijzen niet fundamenteel zijn gewijzigd.

\section{Discussie en conclusie}

Het bij elkaar brengen van data uit verschillende bronnen maakt innovaties mogelijk die niet door individuele partijen gedaan kunnen worden. Platformen waarin data van tal van bedrijven samenkomen, kunnen zowel bedrijfsfunctionaliteit als rapportages richting de overheid ondersteunen. Dit biedt de overheid een kans om effectiever, efficiënter en faciliterend te werken. Platformen kunnen helpen zowel horizontale integratie (tussen interacterende organisaties) als verticale integratie (gedeelde services voor meerdere instanties) te faciliteren, wat voordelen biedt voor bedrijven en overheidsinstellingen. Maar tenzij de overheid zelf een platform bouwt en deelname gaat afdwingen, is de opzet van zo'n plat- 
form gebaseerd op vrijwilligheid, wat betekent dat al in het ontwerp ervan ruimte moet worden geboden aan allerhande partijen. Als de overheid een te grote of sturende rol gaat spelen, bestaat het risico dat het 'gewoon' als een extra overheidssysteem wordt (gezien), waarin bedrijven ongetwijfeld hun formele verplichtingen zullen nakomen, maar er weinig ruimte is voor nieuwe, nog onvoorziene, innovaties. Daarbij komen kosten voor ontwikkeling en exploitatie dan voor rekening van de overheid.

In dit artikel is het ontwikkeltraject van een informatieplatform geanalyseerd vanuit het perspectief van innovatiemanagement. Op theoretisch vlak is de belangrijkste bevinding dat de drie perspectieven niet noodzakelijk concurreren. De casus laat zien dat een innovatietraject niet beperkt is tot één aanpak, maar dat er diverse fases te onderscheiden zijn waarin strategieën vanuit alle drie worden gebruikt. Voor een innovatietraject kan het nuttig of zelfs noodzakelijk zijn om een aantal van deze fases te doorlopen.

Misschien is het voor deze processen wel nodig er op de moeilijke manier achter te komen dat zoveel actorcomplexiteit zich niet in een top-down noch een bottom-up strategie laat vangen. In dit geval heeft de overheid een stip op de horizon gezet die verder weg van de bestaande situatie bleek te liggen dan gehoopt. Dat is goed te verklaren vanuit de diversiteit aan belangen, niet alleen bij de private partijen, maar ook bij de overheid. Het lokaal bestuur heeft hierin andere doelen dan uitvoeringsorganisaties en ministeries, die ook onderling weer andere accenten leggen. Doordat de visie geoperationaliseerd moest worden in concrete stappen, werden die verschillen blootgelegd en relevant. Dat schept een nieuwe werkelijkheid voor het innovatieproces, waarbij de specifieke belangen en rollen van partijen en de lokale context expliciet zijn geworden, wat vervolgens een plek moet krijgen in het proces. Hierin is het lokaal bestuur eerder een belangenbehartiger van de Rotterdamse havengemeenschap, terwijl de uitvoeringsorganisaties vooral zelf een belang bij het platform hebben.

Meer praktisch laat de analyse zien dat het ondanks hoge verwachtingen erg lastig te realiseren is overheden te laten meeliften op private dataplatformen, zeker in een situatie met zoveel actorcomplexiteit als hier. Hoewel er vanaf begin af aan is gewerkt aan een inclusieve governancestructuur om de ontwikkeling en implementatie van het platform in goede banen te leiden, bleek het lastig om daarmee ook echt een platform op vlieghoogte te krijgen. Het vinden van een balans tussen autonomie en control, het zoeken naar businesscases die aansluiten bij de belangen van een diverse set aan publieke en private partijen, en het opzetten van een samenwerkingsproces voor zowel bestuur als infrastructuur lijken essentiële ingrediënten om de transformatie te laten werken. Als de overheid daadwerkelijk het initiatief aan de private sector wil laten, moet zij nadenken over de prikkels waarmee bedrijven kunnen worden bewogen om meer data te delen, en daar innovatief gebruik bij ontwikkelen om de informatievoorziening richting de overheid mee te versterken. In de casus bestonden die prikkels onder andere uit de belofte om overheidsprocessen te optimaliseren, zodat het platform kan bijdragen aan administratieve-lastenreductie. Het tijdiger en geïntegreerd delen van betere 
informatie zou ook de mogelijkheden voor horizontaal toezicht kunnen vergroten, wat in theorie tot minder inbreuken in de logistieke keten zou leiden. Tenminste voor die partijen die ruimhartig informatie delen en toepassingen ondersteunen ten behoeve van het aantonen van compliance. Uiteindelijk moet er een vorm worden gevonden om om te gaan met het gegeven dat langetermijninnovaties onvermijdelijk zullen botsen met de directe belangen van een deel van de partijen. Daarbij versterkt een informatieplatform de wederzijdse afhankelijkheden tussen partijen, wat voor partijen ronduit bedreigend kan zijn, omdat hun presteren voor een deel zal gaan afhangen van een platform waarover ze geen of zeer beperkt controle hebben. In deze casus is er lang geen goed model voor platformgovernance gevonden om deze uitdagingen het hoofd te bieden. Mede als gevolg daarvan is er sprake van flinke uitloop en aanzienlijk bijgestelde verwachtingen.

Voor het lokaal bestuur is dit inzicht relevant, gelet op zijn belang bij het betrekken van partijen die belangrijk zijn voor de gemeente of lokale bedrijvigheid. Waar datagerelateerde innovaties een infrastructurele component krijgen, zoals hier met het platform, lijkt een stevige nationale agenda haast onvermijdelijk. Het kan ook wenselijk zijn, bijvoorbeeld om toekomstige fragmentatie te voorkomen. Tegelijkertijd staat zo'n nationaal platform soms erg ver af van de kleine en middelgrote partijen die juist lokaal zo van belang zijn. Een innovatiestrategie waarbij vooral wordt uitgegaan van lokale waardecreatie past dan veel beter. Om daarin toch aansluiting bij een overkoepelende agenda te realiseren lijkt een aanpak waarin innovaties in lokale niches worden gerealiseerd, maar beschermd vanuit een nationaal kader, beloftevol. Een eerste stap richting complexiteitsbeheersing kan worden gezet als de diverse betrokken overheidspartijen gezamenlijk een positie en strategie bepalen, waarbij het lokaal bestuur de aansluiting met de (bedrijfs)gemeenschap inbrengt.

\section{Literatuur}

Ansell, C. \& A. Gash, 'Collaborative governance in theory and practice', Journal of Public Administration Research and Theory, 2007/4, p. 543-571.

Barringer, B.R. \& J.S. Harrison, 'Walking a tightrope. Creating value through interorganizational relationships', Journal of Management, 2000/3, p. 367-403.

Bharosa, N., M.F.W.H.A. Janssen, R. van Wijk, C.P.I. de Winne, H.G. van der Voort, J. Hulstijn \& Y. Tan, 'Tapping into existing information flows. The transformation to compliance by design in business-to-government information exchange', Government Information Quarterly, 2013/1, p. 9-18.

Boon, W.P.C., E.H.M. Moors \& A.J. Meijer, 'Exploring dynamics and strategies of niche protection', Research Policy, 2014/4, p. 792-803.

Bruijn, J.A. de \& E.F. ten Heuvelhof, Management in networks, Londen: 2018 (tweede druk).

Bruijn, J.A. de, H.G. van der Voort, W. Dicke, M. de Jong \& W. Veeneman, Creating system innovation. How large scale transitions emerge, Boca Raton, FL: 2004.

Bryson, J.M., B.C. Crosby \& M.M. Stone, 'The design and implementation of cross-sector collaboration. Propositions from the literature', Public Administration Review, 2006/ december (special issue), p. 44-55. 
Cusumano, M.A., 'Google. What it is and what it is not', Communications of the ACM, 2005/2, p. 15-17.

Eaton, B.D., The dynamics of digital platform innovation. Unfolding the paradox of control and generativity in Apple's iOS, dissertatie London School of Economics and Political Science (LSE), Londen: juni 2012.

Eaton, B.D., S. Elaluf-Calderwood, C. Sørensen \& Y. Yoo, 'Distributed tuning of boundary resources. The case of Apple's iOS service system', MIS Quarterly, 2015/1, p. 217-243.

Estermann, B., M. Fraefel, A.C. Neuroni \& J. Vogel, 'Conceptualizing a national data infrastructure for Switzerland', Information Polity, 2018/1, p. 43-65.

Gawer, A., 'Bridging differing perspectives on technological platforms. Toward an integrative framework', Research Policy, 2014/7, p. 1239-1249.

Gestel, N.M. van, J.F.M. Koppenjan, I. Schrijver, A. van de Ven \& W. Veeneman, 'Managing public values in public-private networks. A comparative study of innovative public infrastructure projects', Public Money \& Management, 2008/3, p. 139-145.

Heiskala, R., 'Social innovations. Structural and power perspectives', T.J. Hämäläinen \& R. Heiskala (eds.), Social innovations, institutional change and economic performance. Making sense of structural adjustment processes in industrial sectors, regions and societies, Cheltenham: 2007, p. 52-79.

Irani, Z., T. Elliman \& P. Jackson, 'Electronic transformation of government in the UK. A research agenda', European Journal of Information Systems, 2007/4, p. 327-335.

Janssen, M.F.W.H.A. \& E. Estevez, 'Lean government and platform-based governance. Doing more with less', Government Information Quarterly, 2013/S1-S8.

Klievink, A.J. \& M.F.W.H.A. Janssen, 'Developing multi-layer information infrastructures. Advancing social innovation through public-private governance', Information Systems Management, 2014/3, p. 240-249.

Klievink, A.J., N. Bharosa \& Y. Tan, 'The collaborative realization of public values and business goals. Governance and infrastructure of public-private information platforms', Government Information Quarterly, 2016/1, p. 67-79.

Klievink, A.J., H.G. van der Voort \& W. Veeneman, 'Creating value through data collaboratives. Balancing innovation and control', Information Polity, 2018/4, p. 379-397.

Klievink, A.J., A.C. Neuroni, M. Fraefel \& A.M.G. Zuiderwijk, 'Digital strategies in action. A comparative analysis of national data infrastructure development', Proceedings of the 18th Annual International Conference on Digital Government Research, Staten Island, NY: 2017, p. 129-138.

Loorbach, D., 'Transition management for sustainable development. A prescriptive, complexity-based governance framework', Governance. An International Journal of Policy, Administration, and Institutions, 2010/1, p. 161-183.

Loorbach, D. \& R. van Raak, Strategic niche management and transition management. Different but complementary approaches (working paper), Rotterdam: 2006.

Lynn, L., C. Heinrich \& C. Hill, 'Studying governance and public management. Challenges and prospects', Journal of Public Administration Research and Theory, 2000/2, p. 233-261.

Markus, M.L. \& Q.N. Bui, 'Going concerns. The governance of interorganizational coordination hubs', Journal of Management Information Systems, 2012/4, p. 163-197.

McGuire, M., R. Agranoff \& C. Silvia, 'Collaborative public administration', Public Administration Review, 2010/1c, p. 1-35.

Meijer, A.J., 'Datapolis. A public governance perspective on "smart cities"', Perspectives on Public Management and Governance, 2018/3, p. 195-206.

Oliver, C., 'Determinants of interorganizational relationships. Integration and future directions', Academy of Management Review, 1990/2, p. 241-265. 
Porter, M.E. \& M.R. Kamer, 'Creating shared value', Harvard Business Review, 2011/1-2, p. 62-77.

Rotmans, J., R. Kemp \& M. van Asselt, 'More evolution than revolution. Transition management in public policy', Foresight, 2001/1, p. 15-31.

Rüede, D. \& K. Lurtz, 'Mapping the various meanings of social innovation. Towards a differentiated understanding of an emerging concept', EBS Business School Research Paper Series, 12/03, Oestrich-Winkel: 2012.

Schot, J. \& F.W. Geels, 'Strategic niche management and sustainable innovation journeys. Theory, findings, research agenda, and policy', Technology Analysis \& Strategic Management, 2008/5, p. 537-554.

Stoker, G., 'Public value management. A new narrative for networked governance?', The American Review of Public Administration, 2006/1, p. 41-57.

Stoker, G., 'Was local governance such a good idea? A global comparative perspective', Public Administration, 2011/1, p. 1531.

Susha, I., M.F.W.H.A. Janssen \& S.G. Verhulst, 'Data collaboratives as "bazaars"? A review of coordination problems and mechanisms to match demand for data with supply', Transforming government. People, process and policy, 2017/1, p. 157-172.

Thomson, A.M. \& J.L. Perry, 'Collaboration processes. Inside the black box', Public Administration Review, 2006/s1 (special issue), p. 20-32.

Tunzelmann, N. von, 'Historical coevolution of governance and technology in the industrial revolutions', Structural Change and Economic Dynamics, 2003/4, p. 365-384.

Verhulst, S.G. \& D. Sangokoya, Data collaboratives. Exchanging data to improve people's lives, New York: 2015, retrieved from https://medium.com/@sverhulst/data-collaborativesexchanging-data-to-improve-people-s-lives-d0fcfc1bdd9a.

Weerakkody, V. \& G. Dhillon, 'Moving from e-government to t-government. A study of process reengineering challenges in a UK local authority context', International Journal of Electronic Government Research, 2008/4, p. 1-16.

Zapf, W., 'The role of innovations in modernization theory', International Review of Sociology, 1991/3, p. 83-94.

Zuiderwijk, A.M.G. \& M.F.W.H.A. Janssen, 'Open data policies, their implementation and impact. A framework for comparison', Government Information Quarterly, 2014/1, p. 17-29. 